\title{
Ideias fora do lugar: a construção do pacifismo stalinista na primeira década da Guerra Fria (1945-1956)
}

\author{
Ideas out of place: the construction of Stalinist pacifismo \\ in the first decade of the Cold War (1945-1956)
}

\section{Jayme Fernandes Ribeiro}

Instituto Federal de Educação, Ciência e Tecnologia do Rio de Janeiro jayme.ribeiro@ifrj.edu.br

Resumo: A Guerra Fria, surgida em fins da década de 1940, com o lançamento da Doutrina Truman, abriu uma nova página na história. O mundo inteiro foi marcado pela sombra de uma nova guerra mundial, que, em determinados momentos, pareceu realmente poder acontecer. As armas nucleares intensificariam ainda mais o temor de um conflito internacional, principalmente, por não ser possível calcular suas proporções. A partir daquele momento, os comunistas passaram a construir uma nova identidade social, a de pacifistas, propagando ideias, símbolos e discursos, através de panfletos e folhetos distribuídos à população e, sobretudo, por intermédio de sua imprensa.

Palavras-chave: Stalinismo, Paz, PCB.

\begin{abstract}
The Cold War, which emerged in the late 1940s, with the launch of the Truman Doctrine, opened a new page in history. The whole world was marked by the shadow of a new world war, which, at certain times, seemed to really be able to happen. Nuclear weapons would further intensify the fear of an international conflict, mainly because it is not possible to calculate its proportions. From that moment, the communists started to build a new social identity, that of pacifists, promoting ideas, symbols and speeches, through pamphlets and leaflets distributed to the population and, mainly, through its press.
\end{abstract}

Keywords: Stalinism, Peace, PCB. 
A história do Partido Comunista do Brasil (PCB) é bastante extensa. De sua fundação, em março de 1922, até sua extinção, em janeiro de 1992, ${ }^{1}$ o partido procurou atuar em todos os campos da sociedade. Em determinados momentos, defendeu a luta armada revolucionária para a implantação do socialismo. Em outros, procurou fazer uma política mais ampla, objetivando ser um verdadeiro partido de massas e defendendo uma luta pacífica, dentro dos meios legais, rumo ao horizonte socialista. Assim o partido atuou junto à sociedade: ora lutando pela paz, ora pela guerra revolucionária; ora fazendo alianças com a burguesia nacional, ora a condenando como "traidora", "vacilante"; ora execrando os sindicatos, durante a linha política do Manifesto de Agosto (1950-1958), ora lutando por sua conquista e por sua ampliação, como na linha de União Nacional (1943-1948). Essas são algumas das diversas ambiguidades existentes no seio do PCB, no decorrer de sua trajetória política.

Não obstante, a partir do fim da Segunda Grande Guerra e, sobretudo, a partir da Guerra Fria, os comunistas passaram a se autointitular os legítimos defensores da paz mundial. Elaboraram uma série de discursos, símbolos e representações de um grupo social dedicado à luta pela paz e de um país - a União Soviética - onde o ideário pacifista era a base de todas as suas ações nas questões internacionais. Utilizando-se, sobretudo de seus periódicos, Tribuna Popular, Voz Operária e Imprensa Popular, a direção do PCB divulgou matérias, construiu discursos e veiculou símbolos, tais como a pomba branca da paz, rotineiramente em suas páginas, num processo de tentativa criação de uma tradição de luta pela paz para o campo soviético.

O objetivo do artigo é o de analisar a construção do ideário pacifista da URSS e sua relação com a elaboração de uma nova identidade para o comunismo internacional, tendo em vista o novo contexto histórico que se inaugurou após a Segunda Guerra Mundial.

\section{A Nova Linha Geral}

\footnotetext{
${ }^{1}$ Será utilizado o nome Partido Comunista do Brasil devido ao período compreendido pelo trabalho. Fundado em março de 1922 com o nome de Partido Comunista do Brasil, Seção Brasileira da Internacional Comunista, e adotando a sigla PCB, somente em agosto de 1961 o Comitê Central do partido modificou os estatutos e sua denominação, passando, assim, a utilizar o nome Partido Comunista Brasileiro, mantendo a sigla. Somente em janeiro de 1992 o PCB sai de cena para dar lugar a seu sucessor: o Partido Popular Socialista (PPS). No entanto, O Partido Comunista Brasileiro foi refundado em Ilhéus, em 1995, não possuindo, porém, a expressão política de outrora.
} 
O período imediatamente posterior à Segunda Guerra Mundial, até 1947, é marcado por uma relativa cordialidade nas relações entre o governo norte-americano e o governo soviético. Entretanto, apesar dos esforços diplomáticos, as coligações não duraram muito tempo, pois os antagonismos das concepções dos EUA e dos países capitalistas, por um lado, e os da URSS e dos países socialistas, por outro, afloraram novamente. O lançamento da "doutrina Truman", em 1947, para muitos pesquisadores, oficializou a Guerra Fria, modificando significativamente o rumo das relações internacionais.

Naquele mesmo ano, a União Soviética, sob a liderança de Stálin, ditou aos partidos comunistas uma nova "Linha Geral" (CLAUDIN, 1970), que representava a adaptação da política desses partidos à resposta que o Kremlin pretendia dar ao curso expansionista de Washington. Nesse momento, fazia-se necessário formar uma ampla frente antiamericana, na intenção de impor aos Estados Unidos um arranjo mundial, baseado na repartição das áreas de influência, que fosse satisfatório para os interesses soviéticos. Como afirma Fernando Claudin,

a ideia tática essencial da nova linha consistia em explorar a fundo as contradições entre a expansão americana e as burguesias nacionais européias ou de outras latitudes; em agrupar - como dizia Zdanov - 'todas as forças dispostas a defender a causa da honra e da independência nacional', e mobilizar a todos os 'partidários da paz' contra o perigo de uma terceira guerra mundial (1970: 525)

Segundo Stálin, isso faria pressão às autoridades políticas norte-americanas e as obrigaria a empreender as resoluções da conferência de Yalta. ${ }^{2}$ Da mesma forma, permitiria aos partidos comunistas do Ocidente empreender o caminho da união nacional seguido até 1947, pela via parlamentarista e pacífica até o socialismo.

Nas palavras de Claudin: "o único aspecto da nova linha que tomou corpo em certa medida, ainda que em um plano quase exclusivamente propagandístico, foi a 'luta

\footnotetext{
${ }^{2}$ Em Yalta, ficaram estabelecidos diversos pontos sobre o fim da Segunda Guerra Mundial e a paz que, logo após, se propunha. A conferência, entre várias questões, estabeleceu: a divisão da Alemanha em zonas de influência pelos países vencedores, dentre eles a URSS; a concessão de territórios à URSS na Ásia e na Europa; um pacto secreto entre Roosevelt e Stálin, pelo qual a URSS deveria receber de volta a Estrada de Ferro Chinesa Oriental, a parte meridional da ilha de Sacalina, as Ilhas Kuril e Porto Arthur; o desmantelamento das indústrias alemães, sobretudo as bélicas; o pagamento de indenização à URSS por danos causados pelos nazistas nos territórios ocupados durante a Segunda Guerra Mundial; entre outros. Ver DEUTSCHER, Isaac. Stalin. A história de uma tirania. Rio de Janeiro: Civilização Brasileira, 1970, vol. 2. (especialmente o capítulo XIII).
} 
pela paz"” (1970: 526). Importa ressaltar que movimentos e apelos reivindicando a paz para o mundo eclodiram até mesmo durante a Segunda Guerra Mundial, e, principalmente, a partir do seu fim. Todavia, o movimento organizado que obteve mais destaque em todo o mundo foi o chamado "Movimento pela Paz". Ele começou em agosto de 1948, onde se celebrou, na Polônia, o Congresso Mundial dos Intelectuais pela Paz e em novembro, na França, o Congresso Nacional dos “Combatentes da Paz”. Além deles, o “Congresso Mundial da Federação Democrática das Mulheres”, em Budapeste, no outono do mesmo ano, e, muito particularmente, o primeiro "Congresso Mundial dos Partidários da Paz", realizado em Paris e em Praga, de vinte a vinte e cinco do abril de 1949, contribuíram grandemente para a divulgação e propagação do "Movimento pela Paz" em todo o mundo. A "luta pela paz", importa ressaltar, confundia-se com a defesa da União Soviética contra as agressões do "imperialismo" norte-americano.

O "Movimento pela Paz" incluía diversas campanhas: apelos e protestos contra a OTAN, contra a Guerra da Coréia, pelo desarmamento geral, contra o envio de soldados brasileiros para a Coréia, contra a guerra atômica (“Apelo de Viena”, 1955), pela proibição das armas atômicas (“Apelo de Estocolmo", 1950), pela adoção de um "pacto de paz" entre as cinco grandes potências do período - EUA, URSS, Inglaterra, França e China - (“Apelo de Berlim”, 1951-1952) etc. Vale lembrar que as campanhas, no Brasil, eram desenvolvidas, articuladas e propagandeadas pelo Partido Comunista do Brasil $(\mathrm{PCB})^{3}$

$\mathrm{Na}$ "luta pela paz", os militantes comunistas deveriam recolher assinaturas através de inúmeros documentos dirigidos à opinião pública e aos governos, assim como aos parlamentares, à Organização das Nações Unidas (ONU) etc. Não apenas reclamando o pacto de paz entre as superpotências, mas também protestando contra a OTAN, reclamando a interdição das armas atômicas, reivindicando o desarmamento geral e apoiando as iniciativas da diplomacia soviética.

Para a compreensão do contexto internacional em que foi criado o "Movimento pela Paz" e, posteriormente, a inserção nesse movimento das "Campanhas Pela Paz", observam-se vários fatores bastante significativos: o envio, para o Uruguai, de bombardeiros do Comando Aéreo Estratégico dos Estados Unidos, armados com dispositivos nucleares, em uma demonstração de força no momento da posse do

\footnotetext{
${ }^{3}$ Para melhor compreensão dessas campanhas no Brasil e no mundo, ver RIBEIRO. Jayme Fernandes (2011). Combatentes da paz: os comunistas brasileiros e as campanhas pacifistas dos anos 1950. Rio de Janeiro, 7Letras/FAPERJ.
} 
presidente do Uruguai em fevereiro de 1947, a Doutrina Truman e o Plano Marshall do mesmo ano, a crise de Berlin (junho de 1948 - maio de 1949), a conclusão da Organização do Tratado do Atlântico Norte (OTAN) em abril de 1949, o comunicado da agência de informação Tass, em 25 de setembro de 1949, confirmando a explosão de uma bomba atômica soviética em abril daquele ano, e revelando que a União Soviética a possuía desde 1947, e a guerra na Coréia, em junho de 1950.

Em novembro de 1949, na reunião do Kominform, a "luta pela paz" foi definida como tarefa central do movimento comunista, a qual deveriam subordinar-se todas as outras tarefas e objetivos. Acreditava-se, naquele momento, numa possível "ação direta" do "imperialismo norte-americano" contra a União Soviética. Os líderes do Kominform diziam que a URSS vivia uma grave ameaça com a escalada armamentista dos EUA, especialmente com seus arsenais atômicos. A intervenção na Coréia, relatavam, era a grande prova da agressividade imperialista. O objetivo prioritário dos revolucionários, portanto, era o de conquistar uma paz "sólida e duradoura" em detrimento de novas revoluções socialistas. De acordo com Stálin, “o atual movimento pela paz se propõe a mobilizar as massas populares na luta pela conservação da paz, por conjurar uma nova guerra mundial. Por conseguinte, não tende a derrubar o capitalismo e a instaurar o socialismo: se limita a fins democráticos de luta pela manutenção da paz"4 (CLAUDIN, 1970: 528).

No Brasil, os revolucionários eram orientados sobre a política de "luta pela paz" da URSS. Diversos "comitês pela paz" foram criados em cidades, bairros, clubes esportivos, fábricas, repartições, empresas etc. Salvo algumas exceções, eram em sua maioria constituídos por comunistas e simpatizantes.

Os militantes comunistas, sob a orientação do PCB, deveriam, por exemplo, colher quatro milhões de assinaturas em favor do "Apelo de Estocolmo", cinco milhões para o "Apelo de Berlim" e dez milhões ao "Apelo de Viena". Cada país tinha uma cota de assinaturas que deveria coletar e, posteriormente, enviar aos respectivos Congressos Mundiais da Paz, que eram realizados uma vez a cada ano, a partir de 1949. Assim, cada partido comunista deveria se empenhar ao máximo para atingir suas cotas. O PCB assumiu a tarefa, divulgando e propagandeando as campanhas em favor da paz.

Uma delas, e a que mais ganhou grande destaque internacional, foi a Campanha pela Proibição das Armas Atômicas, também conhecida como "Apelo de Estocolmo".

\footnotetext{
${ }^{4}$ Discurso proferido por Stálin, na reunião do Kominform, em novembro de 1949.
} 
Ao realizar sua terceira sessão plenária, em março de 1950, o comitê do Congresso Mundial dos Partidários da Paz pretendia fazer um balanço das lutas pela paz que se desenvolveram e se intensificaram nos primeiros meses do ano, e trocar experiências para prossegui-las de modo mais elevado, com a finalidade de conjurar as ameaças de guerra que então se agravavam. O comitê adotou importantes resoluções para a luta dos partidários da paz em todo o mundo, que foram transcritas, no Brasil, pelo jornal Voz Operária (1/4/1950, p. 4):

1) Chamamos todos os homens de boa vontade para um novo Congresso Mundial da Paz, a realizar-se na Itália no $4^{\circ}$ trimestre de 1950.

2) Convidamos para este Congresso todas as coletividades sociais, religiosas e culturais, todas as pessoas de bem, quaisquer que sejam as suas opiniões sobre a origem da atual tensão internacional, que se preocupam e desejam sinceramente o restabelecimento das relações pacíficas entre as nações.

3) Submetemos a todos, como ponto para um acordo, a proibição da arma atômica e a condenação de qualquer governo que, em primeiro lugar, dela fizer uso.

Ainda segundo Voz Operária, na ocasião o comitê lançou também um apelo assinado por seu presidente, o cientista francês Fréderic Joliot-Curie, nos seguintes termos:

Exigimos a proibição absoluta da arma atômica, arma de terror e extermínio em massa de populações.

Exigimos ao mesmo tempo o estabelecimento de um rigoroso controle internacional que assegure a aplicação da medida de interdição.

Consideramos que o governo que primeiro utilizar a arma atômica, não importa contra que país, terá cometido um crime contra a humanidade e deverá ser considerado criminoso de guerra.

Pedimos a todos os homens de boa vontade que assinem este apelo.

O "Apelo de Estocolmo", lançado em 15 de março de 1950, mobilizou comunistas de todo o mundo, que se engajaram com disciplina e determinação na Campanha. Aqueles que participavam ativamente, colhendo assinaturas em cópias do apelo, em sua maioria militantes comunistas, eram chamados de "combatentes da paz". 
Atendendo ao "Apelo", cada país tinha uma cota de assinaturas que deveria coletar para enviar ao II Congresso Mundial da Paz, que ocorreria em outubro de 1950, na Inglaterra. ${ }^{5}$ No Brasil, os militantes comunistas, sob a orientação do PCB, deveriam colher quatro milhões de assinaturas. A campanha começou em março de 1950 e de veria se encerrar em 30 de setembro, data de entrega das cotas de todos os países participantes do congresso.

É preciso ressaltar que grande parte dos jornais da grande imprensa (não comunista) denunciava a referida campanha e todo o "Movimento pela Paz" como sendo parte integrante dos planos soviéticos para aumentar suas áreas de influência e espalhar o comunismo por todo o mundo.

A grande imprensa anunciava, cada vez mais, que a União Soviética era um “obstáculo intransponível” no que concernia às questões relativas a um acordo de paz internacional.

O Jornal, em 21 abril de 1950, publicou um artigo de primeira página intitulado "CAMPANHA MUNDIAL PELA VERDADE CONTRA O COMUNISMO”. O artigo preocupava-se em demonstrar o apelo do presidente dos Estados Unidos à imprensa dos “países livres” em prol de uma campanha de divulgação da realidade democrática em todo o mundo. Num discurso pronunciado perante à Sociedade Americana de Diretores de Jornais, Truman apelou para a imprensa no sentido de que lhe ajudasse a derrubar ou transpor as barreiras que se levantaram às "comunicações livres no mundo". Era necessária uma "campanha pela verdade, contra a propaganda russa". Nas palavras do presidente, "se não conseguirmos fazer chegar histórias genuínas aos outros países, perderemos, por falta de ação, a batalha pela conquista da mentalidade humana”.

Não sem razão, Baczko revela que o domínio do simbólico é extremamente importante para que um grupo ou classe social possua, de maneira eficaz, o controle sobre determinado grupo. Para o autor, “é significativo que as elites políticas se deem rapidamente conta do fato de o dispositivo simbólico ser um instrumento eficaz para influenciar e orientar a sensibilidade coletiva, em suma, para impressionar e eventualmente manipular as multidões" (1985: 324). O controle do simbólico mostra-se

\footnotetext{
${ }^{5}$ No decorrer dos preparativos para o II Congresso Mundial da Paz, que seria realizado em Sheffield, na Inglaterra, entre os dias 21 e 23 de outubro, uma decisão surpreendeu os "partidários da paz" de todo o mundo: o governo inglês não autorizou a realização do congresso em seu país. Os responsáveis rapidamente transferiram o encontro para Varsóvia, na Polônia, no período de 16 a 23 de novembro.
} 
grandemente relevante para o controle efetivo daqueles que se quer dominar. Merece destacar que os símbolos só são eficazes quando assentados numa "comunidade de imaginação". Se essa não existe, eles têm tendência a desaparecer da vida coletiva ou, então, a serem reduzidos a funções puramente decorativas. Analisando a questão da Guerra Fria, tal comunidade não apenas existia, como também impulsionava a fabricação de valores, crenças e ideias que povoavam o imaginário de todos aqueles que viveram direta ou indiretamente a disputa política na arena internacional. Ambos os antagonistas, cada qual à sua maneira, procuravam fabricar os seus mitos e estabelecer as suas verdades. Não apenas disputavam o controle de determinados países e/ou regiões de influência, mas também o controle do imaginário social. Concomitante a disputa por bens materiais, disputavam acirradamente bens simbólicos, imateriais, porém, não menos reais e importantes. A preponderância na veiculação de imaginários e no seu controle era de extrema relevância. Com isso, podiam passar ao mundo seu modo de vida, seu modelo político e econômico. Enfim, toda uma série de valores e crenças que podiam auxiliar na conquista de novos aliados políticos, parceiros econômicos e novas áreas de influência.

É a partir dessas indicações teóricas que interpretamos a fala de Truman:

Em toda a parte onde a propaganda do totalitarismo comunista for divulgada, temos de enfrentá-la e vencê-la, com informações honestas sobre a liberdade e a democracia. (...) Em muitos países, atualmente, os jornais só publicam do exterior o noticiário que o governo lhes permite. Nada podem acrescentar ou cortar. Nas democracias os jornais gozam de total liberdade (O Jornal, 21/04/1950, p. 01).

O presidente dos Estados Unidos mostrava sua preocupação quanto ao desenvolvimento da propaganda comunista nos países capitalistas ocidentais e no seu próprio. Para ele, tal propaganda, no mundo inteiro, consistia em falsidades, distorções e mentiras. Assim, fazia-se necessário impedi-las.

Vale lembrar que a imagem do comunismo em países ocidentais, e no caso específico do Brasil, era muito negativa. Os comunistas eram vistos como "inimigos da pátria" (MARIANI, 1998) e a grande imprensa não se cansava de publicar artigos e manchetes confirmando essa ideia. Pode-se notar, através da análise das fontes, que o objetivo principal era revelar a verdadeira face do inimigo e suas reais aspirações, ao 
mesmo tempo em que constituía-se a sua própria. Segundo Bethania Mariani, "no campo do outro, a diferença comunista é representada como compromissada com o Mal: ela ameaça os valores cristãos, as propriedades, a ordem, os bons costumes etc. Assim sendo, na imprensa de referência não pode haver espaço para os dizeres comunistas" (1998: 86). Dessa forma, o discurso jornalístico vai atender a disjunção Bem versus Mal, construída em torno da moralidade ocidental cristã, separando em dois campos antagônicos os sentidos possíveis - que, no dizer de Mariani, "o sentido, o bom sentido, o sentido comum, o consenso" (Idem) - daquilo que não faz sentido. E o que não faz sentido, proibido e impossível, é o que não está adequado à ética e/ou à moralidade judaico-cristã, isto é, o comunismo.

Assim, o discurso dos jornais da grande imprensa procurava veicular ideias e atuar na constituição da figura do PCB no imaginário ocidental e, mais especificamente, do comunista como o outro inimigo. Com isso, o reconhecimento do comunista como "Outro", em vez de propiciar a sua assimilação ao discurso do direito à diferença, produziu sua assimilação para o campo do Mal, do "mau Outro". Como destaca Mariani, "contra esse inimigo-estrangeiro-outro se reafirma a docilidade, a cordialidade, a religiosidade cristã do brasileiro" (1998: 90). Quem fugisse a essa lógica seria considerado um "mau brasileiro", um "traidor" da pátria. Assim, ao se negar o comunismo, por inseri-lo no campo do "Outro" - do "mau Outro", do inimigo dos valores ocidentais e cristãos -, reafirmava-se, cada vez mais, uma identidade brasileira no campo do "Mesmo", do consenso, do bom senso, enfim, do imaginário ocidental cristão. A negação do PCB está, sem dúvida, relacionada à confirmação do modelo ocidental. Dessa maneira, enfatiza a autora, "a situação da exclusão do comunismo como outro indesejável, mas necessário à afirmação do mesmo, também se encontra reiterada na grande maioria dos artigos assinados, bem como nas vozes que são citadas pelos jornais" (1998: 90).

Controlar os meios de construção dos imaginários sociais tornava-se de extrema importância, assim como utilizar os mesmos métodos do inimigo na elaboração de imaginários. Mas, não apenas isso. Havia a necessidade de elaboração de novos e mais sofisticados métodos de produção e divulgação desses mesmos imaginários, a fim de garantirem o sucesso e a aceitação de uma ideologia.

Haja vista que o PCB fora posto na ilegalidade em 1947, o comunismo perseguido em âmbito internacional pela política externa dos Estados Unidos e o contexto, cada vez mais acirrado, da Guerra Fria, verificava-se a necessidade de 
perseguir os militantes comunistas e simpatizantes em todas as atividades e manifestações a que se dirigiam. Não foi diferente em relação às campanhas do "Movimento pela Paz". Segundo os relatos da imprensa não comunista,

o Kominform ordenou aos comunistas de todo o mundo o lançamento de uma campanha contra a bomba atômica. Estão angariando por toda parte assinaturas para uma demonstração colossal de hostilidade ao emprego das armas à base de energia nuclear, na hipótese de uma guerra (O Jornal, 30/5/1950, p. 2).

Para a grande imprensa, é claro, as campanhas de "luta pela paz" faziam parte da estratégia comunista de avançar suas áreas de influência pelo mundo. Evidentemente, dizia o periódico, os comunistas iriam recolher um número elevado de assinaturas. Havia milhões de pessoas que viam na bomba atômica, antes de tudo, o elemento de destruição em massa, capaz de aniquilar cidades inteiras e até países, com um grande furor. Entretanto, salienta o artigo, “a adesão dos democratas ao movimento encomendado pelo Kominform não pode nem deve traduzir uma atitude de incompreensão em face de um problema que só existe porque a União Soviética se tem recusado sistematicamente a contribuir para a sua resolução" (O Jornal, 30/5/1950, p. 2).

Por essa razão, diversos panfletos distribuídos pelos militantes nas ruas, em portas de fábricas, colégios, levados de casa em casa etc., procuravam contradizer a imprensa não comunista, mostrando que as "Campanhas" eram apenas apelos em favor da paz. Além disso, atendia aos anseios de milhares de pessoas do mundo inteiro.

Em um dos panfletos distribuídos à população, os comunistas iniciavam seus esclarecimentos da seguinte maneira:

Aos Que Afirmam:

"Essa campanha pertence a um partido político"

DIZEMOS:

"O Apelo de Estocolmo foi lançado por diversas personalidades de renome mundial e pertencentes a correntes políticas as mais diferentes. A primeira assinatura foi a do grande sábio francês Joliot-Curie. Com ele assinaram mais de cem pessoas de fama internacional, tais como Madame Coiton, presidente da Federação Internacional das Mulheres, General Lázaro Cárdenas, ex-presidente do México, o ex-procurador geral dos Estados 
Unidos, John Rogger, amigo e colaborador de Roosevelt, o escritor soviético Illya Ehrenburg, o abade católico Jean Boulier, o líder sindical mexicano Lombardo Toledano, Pietro Nenni, presidente do Partido Socialista italiano e o Deão de Canterbury, além de outros. São essas algumas personalidades que compõem o Comitê Permanente eleito no Primeiro Congresso dos Partidários da Paz realizado em Paris e em Praga em abril de 1949, cujos delegados representavam 600 milhões de seres humanos" (Arquivo Nacional. MJ/Segurança Nacional. Panfletos $\mathrm{Ij}^{1}$ 1325, ano de 1950).

O panfleto continuava afirmando que a campanha não servia aos interesses de um país ou governo. Retratava que o "Apelo de Estocolmo" limitava-se a colocar três simples questões: a proibição da arma atômica, o controle que garantisse essa proibição e a condenação como criminoso de guerra do governo que primeiro a utilizasse. É interessante notar que a fim de melhor esclarecer que a campanha não era uma articulação comunista e que a URSS não tinha o menor interesse em fazer guerra, confirmava que a bomba atômica não era monopólio de um só país, deixando-se entender que já existia a arma atômica soviética, e que ela sendo a favor da paz não aceitaria as provocações de guerra dos norte-americanos. Merece destacar que isso fazia parte da propaganda comunista, onde o par antagônico Bem versus Mal era constantemente explorado. Os comunistas, através de sua imprensa, apresentavam-se como os verdadeiros salvadores da humanidade e preservadores da paz, enquanto os Estados Unidos e os países capitalistas eram destruidores de vidas humanas e exploradores dos países que queriam ser livres.

A disputa pelos discursos, ideias e imaginários sociais estavam presentes nas imprensas comunista e não comunista. Tanto uma quanto a outra procurava desmascarar o farsante, ao mesmo tempo em que se arrogavam os verdadeiros defensores da paz mundial.

\section{A construção do ideário pacifista soviético no pós-1945}

Nos jornais comunistas, podia-se perceber que a defesa da humanidade dependia, principalmente, dos esforços da União Soviética e das democracias populares, enquanto que os países ocidentais, liderados pelos Estados Unidos, representavam os grandes 
incentivadores do conflito nuclear e, particularmente, os iniciadores de uma catástrofe mundial.

Não se pode esquecer que a imprensa não comunista retratava a campanha pacifista da União Soviética como uma enorme falsidade. Segundo relatos da imprensa, a URSS era a verdadeira responsável pelas diversas tentativas infrutíferas de acordos internacionais de redução de armamentos, de controle da energia atômica e propostas de paz. O governo brasileiro, inserido na política da Guerra Fria e apoiando as decisões da diplomacia norte-americana, põe-se a condenar as campanhas organizadas pelo PCB e a persegui-las. O combate ao comunismo, após a ilegalidade do Partido, em 1947, estava na ordem do dia. O "Movimento pela Paz" e suas campanhas foram duramente perseguidos e reprimidos, apesar de não terem sido postos na ilegalidade. Como os comunistas eram os responsáveis pela sua divulgação e propaganda, assim como pela coleta de assinaturas, foram considerados, desse modo, "subversivos" e "perturbadores da ordem", pelos dirigentes do governo brasileiro. Nesse caso, fazia-se necessário combatê-los. ${ }^{6}$ O jornal A Hora, num artigo publicado pelo próprio Departamento de Ordem Política e Social, revelava:

O Departamento de Ordem Política e Social expediu o seguinte comunicado:

"A lei n⿳ำ 1.207, de 25 de outubro de 1950, em seu artigo 1.o, exclui o direito de reunião, quando esta vise a prática de ato proibido. [...] Ora, a Constituição e seu autorizado intérprete, como é o Superior Tribunal Eleitoral, declara ilegal, inconstitucional, o funcionamento do Partido Comunista e, implicitamente, o de todas as organizações que lhe são filiadas" (Arquivo Público do Estado do Rio de Janeiro (APERJ). Dossiê - DPS - Polícia Política, Dossiê n ${ }^{\mathrm{o}}$ 30060). ${ }^{5}$

Assim, de acordo com a interpretação que faziam da lei, os órgãos de repressão passaram a combater os comunistas e suas campanhas em favor da paz. Já que o PCB era um partido ilegal, quando fosse comprovada a participação de seus membros em

\footnotetext{
${ }^{6}$ RIBEIRO, Jayme Fernandes. “Os 'inimigos da paz': Estado, imprensa e a repressão ao movimento dos partidários da paz no Brasil (1950-1956)". Saeculum - Revista de História, [17]; João Pessoa, jul/ dez. 2007.

${ }^{5}$ Nas citações dos jornais e documentos de época, preferiu-se optar pelo modelo de cópia fiel. Isto é, as fontes citadas ao logo do texto apresentam, às vezes, uma grafia incorreta. Portanto, o leitor poderá encontrar muitas palavras com acentuação e pontuação incorretas, termos utilizados que, hoje, não são comuns e vírgulas fora do lugar.
} 
qualquer atividade política e social, lá estaria a lei, através de seus órgãos policiais, para fazer valer a Constituição e punir seus perturbadores.

Nesse sentido, no qual o PCB procurava produzir um imaginário pacifista e construir uma nova memória, a partir de artigos, boletins e documentos sobre o seu passado, deve-se destacar uma questão bastante relevante: em inúmeros artigos, a partir de 1947, a classe operária, que seria a verdadeira vanguarda na luta revolucionária, também seria a campeã na luta pela paz. A partir daquele ano, com o advento da Guerra Fria, a imagem da União Soviética juntava-se ao lado do proletariado: ambos como verdadeiros defensores da paz.

Em 15 de abril de 1950, em sua página seis, o jornal Voz Operária publicou um artigo de página inteira intitulado: "A U.R.S.S. - CAMPEÃ DA PAZ MUNDIAL", revelando que o "país dos sovietes" havia sido o primeiro a propor a proibição das armas atômicas. Segundo o artigo,

DESDE O DIA em que os imperialistas norte-americanos criminosamente, utilizaram a bomba atômica contra a população civil de duas grandes cidades no Japão, quando o Exército soviético levava a derrota esmagadora e irremediável o grosso das forças japonesas na China e na Manchúria, a consciência dos povos passou a exigir a proibição das armas atômicas.

Até mesmo antes de 1950, mas, sobretudo, a partir da primeira campanha desenvolvida pelo PCB, contra as armas atômicas, vários artigos sobre o pacifismo soviético foram publicados na imprensa comunista. A partir desse ano, os jornais comunistas, de uma maneira geral, passaram a publicar uma série de artigos mostrando o que tinha "sido a luta dirigida pela URSS visando à proibição das criminosas armas atômicas como armas de guerra e a utilização da energia atômica para fins pacíficos" (Voz Operária. 15/4/1950, p. 6). Um deles demonstrava que o governo soviético, desde o fim da Segunda Guerra Mundial, lutava incansavelmente no sentido de fazer valer a proibição das armas atômicas em quaisquer tipos de conflito e continuaria a fazer os mais ingentes esforços para a consolidação da paz entre as nações. De acordo com a imprensa comunista,

Desde da primeira reunião da Comissão Atômica da ONU, a 19 de junho de 1946, o representante da URSS, Andrei Gromiko, propôs uma resolução a ser adotada por todos os países: "PROJETO DE CONVENÇÃO 
INTERNACIONAL PARA PROIBIR A PRODUÇÃO E A UTILIZAÇÃO DAS ARMAS ATÔMICAS BASEADAS SOBRE O USO DO ENGENHO ATOMICO” (Voz Operária. 15/4/1950, p. 6).

Assim, declarava o artigo, "toda a atividade da URSS, no após-guerra, em favor da consolidação paz mundial, tem [destino] à proibição da arma atômica ou como requisito prévio da mais alta importância para afastar o perigo de guerra" (Voz Operária. 15/4/1950, p. 6).

Outro artigo sobre o "pacifismo soviético" podia ser lido no jornal Voz Operária. No artigo, a URSS, “campeã da paz”, lutava pelo controle internacional da energia atômica. Mais uma vez, a União Soviética encaminhava-se à ONU para apresentar outra proposta de paz e pela proibição das armas atômicas. Representada por Andrei Gromiko, desde 11 de junho de 1947, a URSS lutava para ser criada uma Comissão Internacional de Controle da Energia Atômica. De acordo com a imprensa, Gromiko, propôs que,

Para assegurar que a energia atômica não será utilizada senão para fins pacíficos, como prevê a convenção internacional sobre a interdição das atômicas e de outras armas principais de destruição maciça; (...) será instituído um controle internacional rigoroso de todas as empresas que se ocupam da extração de matérias-primas atômicas, ao mesmo tempo que as empresas que produzem materiais atômicos ou energia atômica ( $\mathrm{Voz}$ Operária. 29/4/1950, p. 8).

Entretanto, o artigo denunciava que, por maior que fosse o esforço da URSS pela proibição das armas atômicas e pela manutenção da paz, os Estados Unidos só estavam preocupados, através de sua "propaganda de guerra", em levar o mundo a uma nova hecatombe mundial, para que pudessem obter mais lucros para suas empresas imperialistas. O governo soviético denunciava as ações do governo norte-americano no atol de Bikini. Para os dirigentes comunistas, as "experiências" atômicas, naquele atol, demonstrariam, uma vez mais, que a bomba atômica era apenas uma "arma de terror", um criminoso instrumento de destruição em massa, "uma ameaça às populações pacíficas”. Segundo o relato do referido periódico, o que os Estados Unidos pretendiam, naquele momento, não era nada menos que "o velho método hitlerista de intimidar pela força das armas. Era uma tentativa inútil de forçar a URSS a aceitar as imposições do 
imperialismo americano. Era a não menos inútil a tentativa de barrar a luta mundial dos povos pela sua libertação das garras do imperialismo" (Voz Operária. 29/4/1950, p. 8).

No que concerne à criação, no imaginário comunista, do mito do pacifismo soviético, no período stalinista, com letras garrafais, num artigo de página inteira, a imprensa comunista anunciava: "14 vezes a URSS Propôs na ONU A Proibição das Bombas Atômicas e o Controle da Energia Atômica" (Voz Operária. 3/6/1950, p. 3). O artigo retratava toda a trajetória da luta da URSS pela interdição das armas atômicas e pela preservação de uma paz sólida e duradoura entre as nações. De acordo com o jornal, o primeiro passo teria sido dado por Andrei Gromiko, em 19 de junho de 1946. Naquele momento, o representante soviético propôs "a assinatura de um convênio internacional, colocando fora da lei a bomba atômica; o controle da produção e a destruição dos estoques de bombas existentes dentro de 90 dias seguintes à ratificação do convênio" (Voz Operária. 3/6/1950, p. 3).

O segundo passo teria sido em 29 de outubro de 1946, onde Molotov, na segunda sessão da ONU, em Nova York, propôs "a redução dos armamentos de todos os países; interdição do emprego da fabricação de armas atômicas, o controle para a energia atômica, para assegurar sua utilização para fins pacificos" (Voz Operária. 3/6/1950, p. 3). Em 14 de dezembro de 1946, segundo a imprensa comunista, houve uma "histórica intervenção de Molotov", na assembléia da ONU, que votou uma resolução de capital importância, por proposta do ministro do Exército soviético, na qual ficava estabelecido que a energia atômica deveria ser controlada internacionalmente, sob a direção do Conselho de Segurança da ONU.

Em 19 de fevereiro de 1947, Andrei Gromiko fez emendas ao relatório da Comissão Atômica da ONU, proposto pelos Estados Unidos. Já em 19 de junho do mesmo ano, Gromiko apresentou à ONU o projeto soviético para a criação de uma Comissão Internacional de Controle da Energia Atômica. Em agosto, também do mesmo ano, afirmou o artigo, a maioria norte-americana da ONU recusou o projeto soviético e declarou, no segundo relatório da comissão atômica, "que não abandonaria os princípios americanos do 'Plano Baruch', baseado no 'monopólio atômico' dos Estados Unidos” (Voz Operária. 3/6/1950, p. 3). Gromiko, desse modo, reafirmou a posição soviética, colocando "fora da lei" a produção e o emprego da arma atômica, visando, ainda, que houvesse um controle internacional sobre aquele tipo energia. Passando para o ano de 1948, em 29 de março, o representante soviético, denunciou "como de inspiração americana uma declaração comum da Grã Bretanha, França, Canadá e China de Chiang 
Kai Shek, pela qual estes países rejeitavam a proposta soviética e apoiavam o chamado 'Plano Baruch' ianque” (Voz Operária. 3/6/1950, p. 3). Em 5 de abril do mesmo ano, Gromiko reafirmou que a URSS estará sempre pronta, depois da conclusão de um acordo sobre a proibição das armas atômicas, a "elaborar outras convenções relativas á distribuição dos contingentes de produção de energia atômica; a organizar a inspeção e a regulamentação das pesquisas sobre a energia atômica" (Voz Operária. 3/6/1950, p. 3). Em 17 de maio daquele ano, mais uma vez, os Estados Unidos recusaram-se a prosseguir as negociações com a União Soviética sobre as questões referentes ao não uso das bombas atômicas em guerras e aos assuntos de manutenção da paz mundial.

Os acordos sobre a energia atômica e a utilização de armas desse tipo baseavamse nos mesmos pontos, como foi possível observar. Todavia, a partir de $1^{\mathrm{o}}$ de outubro de 1948, o governo soviético, através do seu representante, Vichinski, criou uma nova proposta: "a redução de um terço de todas as forças armadas, terrestres, navais e aéreas das 5 grandes potências (URSS, Estados Unidos, Inglaterra, França e China.)" (Voz Operária. 3/6/1950, p. 3). Em oito de outubro do mesmo ano, a União Soviética renovou a proposta de Vichinski, na reunião da ONU, realizada no palácio Chaillot, em Paris. Além disso, o ano de 1949 também foi marcado por manifestações e propostas pacifistas por parte da URSS. O governo soviético, em 25 de fevereiro, renovou, numa assembleia da ONU, a proposição de Vichinski. Já em 20 de julho, declarou o jornal: “tendo o representante dos Estados Unidos, Osborn, pedido para que fossem suspensos os trabalhos da Comissão Atômica da ONU, o representante soviético Manuilski renova as propostas soviéticas, sobre as quais não há nem um voto dos representantes dos países capitalistas" (Voz Operária. 3/6/1950, p. 3).

Por fim, completando o histórico das quatorze proposições de paz feitas pela União Soviética, em 23 de setembro de 1949, Vichinski propôs: "A proibição incondicional da utilização de armas atômicas e o estabelecimento de um controle internacional adequado e rigoroso; A conclusão de um pacto de paz entre as 5 grandes potências" (Voz Operária. 3/6/1950, p. 3).

Pode-se se perceber que os dirigentes soviéticos procuravam apresentar a URSS como a verdadeira defensora da paz. Desde o final da Segunda Guerra Mundial, preocupava-se com a segurança do mundo, principalmente em defender as populações pacíficas, como era dito, insistentemente, em sua imprensa. As nações do mundo inteiro não estariam seguras, se não houvesse uma proposta cabal e definitiva sobre o controle da energia atômica. Os Estados Unidos, por sua vez, conforme apresentava a imprensa 
comunista, possuidores de bombas atômicas, não estavam dispostos a parar ou até mesmo reduzir sua produção. Sobre cada proposta de paz soviética, concluía um dos artigos, "cada vez as potências imperialistas responderam: Não!" (Voz Operária. 3/6/1950, p. 3).

Dessa forma, os dirigentes comunistas procuravam mostrar toda a trajetória pacifista da União Soviética, desde o final da Segunda Guerra Mundial. Criando um momento fundador, para aquela conjuntura - a primeira proposta de Gromiko, em 19 de junho de 1946 -, o governo soviético procurava passar ao mundo e aos seus militantes, que estavam lutando em favor do bem da humanidade, por uma causa grandemente nobre, interditando a ação das bombas atômicas, sua fabricação e o controle de sua energia, salvaguardando, assim, a consolidação da paz entre todas as nações. Por sua vez, os Estados Unidos procuravam, sistematicamente, combater a proliferação dos ideais comunistas pelo mundo e, sobretudo, em sua própria sociedade. Para isso, era preciso lançar mão de mitos e imagens que desarticulassem a corrente e condicionassem a população a uma visão maniqueísta. Desse modo, como relata Vizentini, "a 'ameaça soviética' e a 'defesa do mundo livre' constituíram esses mitos mobilizadores e legitimadores da nascente Guerra Fria" (2000: 202). No entanto, na outra margem dos acontecimentos, estava a União Soviética, utilizando-se do ideário pacifista e aproveitando-se dele para veicular, no imaginário social, um conjunto de ideias, crenças e imagens de uma nação amante da paz e protetora dos povos.

Todavia, não se pode dizer que a União Soviética, sob Stálin, era de fato pacifista. É importante destacar que, em 1962, o governo soviético publicou um livro intitulado A estratégia militar. O livro apresentou um histórico das ações soviéticas na disputa com o mundo capitalista e, entre outras questões, oito postulados. O primeiro revelava que o desencadeamento de uma guerra contra a União Soviética ou contra um outro Estado "socialista" se ampliaria até constituir um conflito mundial. O segundo dizia que o conflito seria um choque entre dois sistemas sociais antagonistas e terminaria pela vitória do comunismo. O terceiro postulado destacava que os foguetes portadores de ogivas termonucleares desempenhariam um papel preponderante, sendo que outros tipos de forças interviriam apenas como complementação. O quarto postulado demonstrava a disposição da URSS na eventualidade de uma guerra nuclear. Dizia que a condução da guerra visaria essencialmente a desferir golpes termonucleares maciços com a finalidade de destruir os recursos nucleares do adversário e de aniquilar seus centros vitais, o que implicaria o fato de que o centro de batalha se deslocaria para as profundezas do 
dispositivo do adversário. Outro ponto defendia uma economia capaz de desenvolver ao máximo o poder de suas forças armadas pode torná-las capaz de aniquilar o agressor durante a fase inicial do conflito (DELMAS, 1979). Enfim, em todos os pontos do livro o tudo ou nada da dissuasão era reforçado pela ameaça de um recurso a um ataque por antecipação. E antes mesmo da publicação da nova estratégia militar, o governo soviético, entre algumas políticas de demonstração de sua intenção não pacifista, incentivou políticas econômicas direcionadas ao setor militar. De acordo com Claude Delmas, "de 1953 a 1957 insistiu-se sobre a mobilidade e a potência de fogo das tropas de combate, acelerando-se a motorização das forças terrestres e procedendo a redução de efetivos" (1979: 78).

Assim, por mais que houvesse militantes e/ou dirigentes do PCUS e, por conseguinte, dos PC's mundiais favoráveis a um processo de luta pela paz, havia setores desses partidos e, sobretudo, na União Soviética, que apostavam numa vitória na corrida armamentista e num confronto militar vitorioso para o campo soviético.

Se a linha pacifista fosse a aspiração geral entre os dirigentes da URSS, por que insistir, na possibilidade de um conflito armado? O desejo de uma luta pela paz chocava-se com interesses militares e com a aposta de uma luta aberta bem-sucedida contra os Estados Unidos. Com isso, é possível perceber que a "coexistência pacífica" não se desenvolveu de maneira linear, mas, sim, alternou crises e distensões durante todo o período de sua existência. Isso mostra que havia disputas e tensões entre os dirigentes do PCUS e entre os diversos setores do partido. Além disso, contribui para relativizar o "pacifismo" soviético do período.

Desse modo, é possível perceber que os comunistas também estavam trabalhando na constituição de uma memória ligada ao pacifismo e à luta pela paz. Como observado anteriormente, a imprensa comunista publicou artigos e matérias mostrando que a URSS lutava pela paz desde a década de 1940. Procurando, com isso, construir e deixar para o campo comunista uma nova memória: a de pacifisas.

Dessa forma, como revela Michael Pollak, "se podemos dizer que, em todos os níveis, a memória é um fenômeno construído social e individualmente, [...] podemos também dizer que há uma ligação fenomenológica muito estreita entre a memória e o sentimento de identidade" (1992: 05). E aqui, então, fica expressa essa relação. Os comunistas, ao (re)construírem sua memória, objetivavam, também, a construção de uma nova identidade: a de pacifistas. É preciso deixar claro que o sentido de identidade aqui trabalhado é o que se refere ao sentido da imagem de si, para si e para os outros; é a 
imagem que um grupo social e/ou político adquire ao longo de sua trajetória de vida referente a ele próprio, a imagem que ele constrói e apresenta aos outros e a si próprio, para acreditar na sua própria representação, mas também para ser percebida da maneira como quer que seja percebida pelos outros.

De acordo com Pollak,

a memória, essa operação coletiva dos acontecimentos e das interpretações do passado que se quer salvaguardar, se integra, [...] em tentativas mais ou menos conscientes de definir e de reforçar sentimentos de pertencimento e fronteiras sociais entre coletividades de tamanhos diferentes: partidos, sindicatos, igrejas, aldeias, regiões, clãs, famílias, nações etc. (1989: 07).

Com isso, conclui o autor, "a referência ao passado serve para manter a coesão dos grupos e das instituições que compõem a sociedade, para definir seu lugar respectivo, sua complementaridade, mas também as oposições irredutíveis" (1989: 07).

Assim, a referência ao passado serve, também, para manter a identidade do grupo social no presente. Por isso, os comunistas recorreram ao passado para se apresentarem e, ao mesmo tempo, se (re)afirmarem defensores da paz. É nesse sentido que se pode interpretar o discurso dos comunistas sobre as origens do seu pacifismo e de luta contra a bomba atômica, das décadas de 1940 e 1950. Além de criarem um momento fundador a proposição de Andrei Gromiko sobre um convênio internacional a favor da proibição das armas atômicas e o controle de sua produção - e uma nova identidade social - a de pacifistas -, tentaram, concomitante a isso, preservá-la, delimitando as fronteiras do que representava o verdadeiro campo pacifista.

\section{Stálin: o campeão da paz!}

Para o movimento comunista, Stálin foi o "campeão da paz", foi aquele que lutou, como nenhum outro estadista, pela paz mundial, pela justiça internacional e pela concórdia entre as nações. Graças a ele, garantia a imprensa comunista em diversos artigos, que milhões de seres humanos seriam poupados dos horrores de uma guerra nuclear (FERREIRA, 2002). Na imprensa comunista, inúmeros artigos apresentavam Stálin como o verdadeiro defensor da paz, como o único que lutava incansavelmente, 
desde o final da Segunda Guerra Mundial, e até mesmo antes, para tornar possível o sonho de milhares de pessoas em todo o mundo: a paz sólida e duradoura entre as nações.

Um artigo da revista Problemas resumiu bem essa ideia. $\mathrm{O}$ artigo, assinado por Luiz Carlos Prestes, intitulava-se: "STALIN - O PORTA ESTANDARTE DA PAZ" (Problemas, $\mathrm{n}^{\mathrm{o}}$ 37). Nele, era descrito toda a trajetória de um homem que desejava e amava a paz. Segundo Prestes,

é evidente para todos que ninguém como ele, o dirigente do mais poderoso país do mundo, da gloriosa União Soviética, que derrotou o nazismo à custa do sacrifício incomensurável de 16 milhões de vidas do seu povo laborioso e bom, da destruição de suas cidades e fábricas, de sua agricultura avançada, ninguém como Stálin tem feito tanto pela paz e pelo entendimento sincero e honesto entre os homens do mundo inteiro (Problemas, $\mathrm{n}^{\mathrm{0}} 37$ ).

Segundo Prestes, para Stálin, a vida de centenas de milhões de seres humanos não podiam depender da "insensatez de um pequeno grupo de canibais que pregam diariamente a necessidade e a fatalidade de novas guerras e da liquidação em massa de populações inteiras por meio de novas armas ultra-modernas" (Problemas, $\mathrm{n}^{\mathrm{o}} 37$ ). Com isso, relatou Prestes, desde que assumiu o governo da União Soviética, após a morte de Lênin, em 1924, Stálin se propôs a lutar incansavelmente pela edificação da paz. Procurava, ainda, dar o primeiro passo nas negociações de paz, declarando que era perfeitamente possível a coexistência pacífica entre os sistemas socialista e capitalista. Muito antes da eclosão da Guerra Fria, no XV Congresso do Partido Bolchevique, em dezembro de 1927, Stálin já dizia: “nossas relações com os países capitalistas são baseadas na possibilidade da coexistência dos dois sistemas opostos" (Problemas, $\mathrm{n}^{\mathrm{o}}$ 37). Assim, desde que passou a governar a URSS, sua luta concentrava-se em "denunciar e desmascarar os provocadores de guerra" e lutar para impedir a deflagração de um novo conflito mundial, preservando, assim, a paz para a humanidade.

Outro artigo extremamente interessante, no que concerne à apresentação de Stálin como o verdadeiro baluarte da paz e à criação de uma identidade pacifista para campo do comunismo, tratava-se de um poema, que o periódico comunista Voz Operária afirmava ser de um militante, embora não revelasse o nome do autor. Segundo o jornal, o poema 
traduzia o apoio do povo brasileiro ao "pioneiro" na luta pela paz. Em suas páginas, Voz Operária declamou:

\section{HINO A STÁLIN}

Estribilho

STÁLIN, STÁLIN

Grande mestre

E guia genial

O teu nome ficou gravado,

Nas páginas

Da História Universal.

Pioneiro na luta pela paz,

Braço forte, punho firme e tenaz,

Tua vida voltaste com lealdade,

Pelo amor, pelo bem da humanidade.

Tua glória, teu valor, homem de aço,

Estão na terra, estão no mar e no espaço,

Nas cidades, aldeias e sertões,

Estão gravados em nossos corações.

Teu roteiro havemos de seguir,

Teu exemplo havemos de imitar,

Não há nada que nos possa impedir,

De lutar e a vitória conquistar.

Tua bandeira há de sempre tremular

Empunhada pelo povo a lutar,

Nesta luta decidida e audaz

Pelo bem, pelo amor e pela paz.

Uberlândia, maio de 1953 (Voz Operária. 1/51954: 03 - suplemento). 
Em que pese o fato de ser praticado nas fileiras comunistas o culto à personalidade, pode-se perceber o novo epíteto de pacifista, acentuado, sobretudo, na primeira década da Guerra Fria. A partir daquele momento, os comunistas brasileiros propagandeavam que o governo soviético, sob Stálin, realizava uma nomeada política de paz, "de luta incessante pelo entendimento entre todos os povos, pelo desarmamento progressivo e pela abolição total e imediata das armas atômicas" (Problemas, $\mathrm{n}^{\mathrm{o}}$ 37). Contudo, uma questão deve ser relativizada, no que concerne à "linha pacifista" da URSS. Uma coisa é o pacifismo de Gandhi, ${ }^{7}$ outra coisa é dizer que a linha política da União Soviética, sob Stálin, era pacifista. Além disso, a linha pacifista, de fato, inspirada por Nikita Kruschev, somente teria sua afirmação depois da morte Stálin. A partir do XX Congresso do PCUS, em 1956, é que se propõe, de maneira cabal, a luta pacífica rumo ao socialismo, já sob forte inspiração da política de "coexistência pacífica".

O que se pode verificar daquela situação histórica vivida pelos comunistas é que o contexto da Guerra Fria e o desenvolvimento da corrida armamentista, principalmente no que concerne à posse da bomba atômica pelos Estados Unidos, causavam uma enorme preocupação ao governo soviético. Assim, as campanhas do "Movimento pela Paz" bem como a construção do seu ideário pacifista assumiriam, na verdade, a tentativa de controle da corrida armamentista por parte da URSS, procurando impedir o desenvolvimento armamentístico norte-americano e proporcionando, ao mesmo tempo, o avanço das pesquisas nucleares soviéticas, preparando-se, com isso, para uma possível guerra nuclear.

Na disputa com os EUA pela vitória na Guerra Fria, a União Soviética, desde a explosão de sua primeira bomba atômica, em agosto de 1949, até a assinatura do Tratado de Não-Proliferação de Armas Nucleares, em 1968, não desacelerou sua indústria de armamentos atômicos nem cessou seus testes nucleares. Seu campo de testes de Semipalatinski, na cidade de Kurchatov (atual Semei, no Kazaquistão), realizou 456 testes nucleares em 40 anos de existência. ${ }^{8}$ Além disso, cada superpotência procurava

\footnotetext{
${ }^{7}$ O líder pacifista indiano, Mahatma Gandhi (1869-1948), foi o principal responsável pela independência da Índia do domínio britânco, em 1947. Sua importância se deu grandemente pelo fato de liderar um processo de luta baseado no projeto de não violência, condenando e criticando qualquer prática de confronto armado com as forças policiais.

${ }^{8}$ De acordo com dados da ONU e do próprio governo do Cazaquistão, o "Polígono", como também fícou conhecido, entre 1949 e 1989, realizou 456 testes nucleares e expôs mais de 500 mil pessoas à radiação, causando uma série de enfermidades e inúmeras vítimas de câncer. $\underline{\mathrm{O} \text { campo de testes onde soviéticos }}$ explodiram quase 500 bombas atômicas. (s.d.) BBC News Brasil. Disponível em https://www.bbc.com/portuguese/internacional. Acesso em: 20 jul. 2019.
} 
obter para si o controle do processo de interdição dos armamentos atômicos. As divergências entre EUA e URSS sobre a aceitação dos planos "Baruch" e "Gromiko" residem nessa disputa. ${ }^{9} \mathrm{O}$ fato é que nenhum dos dois países aceitava a liderança um do outro nesse assunto. Desse modo, é preciso relativizar algumas questões: se o governo de Stálin estivesse lutando por uma paz sólida e duradoura e pelo fim dos armamentos nucleares desde 1946, como pregavam constantemente, por que insistir em realizar testes e fabricar sua bomba em 1949? Por que insistiu no desenvolvimento de suas pesquisas e conseguiu fabricar, primeiro que os Estados Unidos, a bomba $\mathrm{H}$ ?

Como revela Diego Holloway, após os acontecimentos de Hiroshima e Nagazaki, Stalin lançou no país "um programa de impacto para construir a bomba soviética" (1997: 153). O objetivo, afinal, era obter o controle da corrida armamentista e a vitória sobre os EUA na Guerra Fria.

\section{Considerações finais}

Sob a liderança de Stálin, os comunistas procuraram construir a identidade de pacifistas, mesmo não priorizando ações práticas para tal fim. Utilizavam, constantemente, em seus manifestos, programas e, sobretudo, em sua imprensa, materiais de propaganda e artigos defendendo serem os verdadeiros responsáveis pela preservação da paz e a quererem o fim das armas nucleares. Por outro lado, continuaram desenvolvendo testes nucleares, incrementando sua indústria bélica (THOMPSON, 1985) e promovendo um discurso incriminador para o campo capitalista e, sobretudo, para os EUA. Em termos de ações práticas, a política pacifista de Stálin no pós-Segunda Guerra Mundial ficou apenas no plano do discurso.

No entanto, aquela conjuntura histórica serviu para os comunistas criarem além de novos mitos políticos - o do pacifismo soviético, Stálin: campeão da paz -, uma nova identidade social e política: a de comunista-pacifista.

É possível compreender que, a partir da análise dos documentos partidários e sua imprensa, os comunistas realizavam um significativo trabalho de "enquadramento da

\footnotetext{
${ }^{9}$ O Plano Baruch foi apresentado à ONU em 14 de julho de 1946 e tinha como objetivo consolidar o controle na internacionalização das minas de urânio e também de tório. Desde o início, a União Soviética rejeitou o Plano por considerá-lo uma ingerência em seus assuntos internos e interferir em sua soberania. Menos de uma semana depois, a URSS apresentou, na ONU, o seu "Plano Gromiko". A proposta soviética era ainda mais radical. Propunha a interdição absoluta das armas atômicas e a destruição dos arsenais existentes até aquele momento. No entanto, tal proposição também foi rejeitada. O argumento foi o de não haver cabimento um país que não possuísse armas atômicas pedir o seu fím. (OLIVEIRA, 1999).
} 
memória” (ROUSSO, 1985). O termo, mais específico que memória coletiva, cunhado por Henry Rousso, refere-se ao fato de que tal enquadramento deve satisfazer certas exigências de justificação, isto é, deve atender a certos preceitos básicos do indivíduo ou grupo social (ROUSSO, 1985). Segundo Michael Pollak,

o trabalho de enquadramento da memória se alimenta do material fornecido pela história. [...] Guiado pela preocupação não apenas de manter as fronteiras sociais, mas também de modificá-las, esse trabalho reinterpreta incessantemente o passado em função dos combates do presente e do futuro. [...] Toda organização política, por exemplo, [...] veicula seu próprio passado e a imagem que ela forjou para si mesma. (1989: 08.)

E com os partidos comunistas não podia ser diferente. A partir do fim da Segunda Guerra Mundial, em 1945, houve todo um trabalho de "enquadramento da memória", para reapropriar e reagrupar o passado em função dos combates políticos do tempo presente. Naqueles anos do imediato pós-guerra, lutar pela paz significava remar a favor da corrente. O tema da paz estava na ordem do dia e na cabeça das pessoas. Nas décadas de 1940 e 1950, era bastante difícil convencer as pessoas, em diversas partes do mundo, que um novo conflito mundial fosse necessário para resolver os problemas oriundos da disputa da Guerra Fria, seja para conter os avanços do comunismo internacional, como pregavam os governos capitalistas, seja para conter o "imperialismo belicista e destruidor", como afirmavam os comunistas.

A Segunda Guerra Mundial, no seu conjunto, afetou, de maneira incontestável, a vida do continente europeu. No entanto, nenhum outro país seria afetado de modo tão catastrófico quanto a URSS. Segundo Reis Filho, “enquanto a União Soviética perdeu 20 milhões de habitantes, entre civis e militares, Estados Unidos, Inglaterra e França, reunidos, tiveram perdas de cerca de 1,3 milhão de pessoas” (REIS FILHO, 1997: 153). Nota-se, portanto, uma diferença significativa, principalmente, ao se considerar que as mortes se associaram, também, a outras perdas, de difícil mensuração, como, por exemplo, invalidez permanente ou temporária, traumatismos, desestruturação de famílias, devastação de propriedades etc. É evidente que Inglaterra e França também foram afetadas. Endividaram-se pesadamente, perderam a condição de grandes potências e sofreram perdas humanas e materiais. Todavia, nada comparável às destruições 
causadas pelos nazistas nas regiões soviéticas ocupadas durante a guerra. Cidades inteiras arruinadas, milhares de aldeias arrasadas. Como relata Reis Filho,

os soviéticos, após o conflito, classificaram 1.710 cidades e cerca de 70 mil aldeias como destruídas, quase metade do espaço urbano, 1,2 milhão de habitações urbanas e 3,5 milhões de habitações rurais gravemente avariadas ou simplesmente riscadas do mapa. A infraestrutura de transporte e comunicações foi violentamente abalada: perdas totais ou graves avarias foram registradas em 65 mil quilômetros de trilhos, 15.800 locomotivas, 428 mil vagões, 4.280 barcos e em metade de todas as pontes nos territórios ocupados. O gado eqüino perdeu dois terços do seu estoque, o suíno quase 85\%. (1997: 154.)

Os dados, em todos os níveis, eram sombrios. A vitória na Segunda Guerra Mundial fora conquistada. Contudo, a um custo extraordinariamente elevado. Para Reis Filho, "este custo marcaria a sociedade por gerações, de uma forma irremediável, acrescentando traumas e patologias inenarráveis" (1997: 155). Ainda, segundo o autor, “em meados dos anos 50, mais de dez anos após o fim da guerra, muitas regiões na URSS ainda não haviam recuperado os níveis demográficos de 1940” (Idem). Dessa maneira, é possível perceber que uma coexistência pacífica, a longo prazo, era um fator que agradava não apenas a população soviética, mas também, de igual forma, a opinião pública internacional. Como salienta Reis Filho, "nunca, talvez, a URSS conhecera, de forma tão generalizada e profunda, tal anseio e confiança numa paz duradoura. Um senso comum" (Idem).

Nesse sentido, quando os comunistas soviéticos orientavam os partidos comunistas de todo o mundo a aderirem a "nova linha geral" e a se engajarem nas campanhas do "Movimento pela Paz", não o faziam sem uma base real. Como anteriormente demonstrado, havia clamores internacionais de paz e um sem número de manifestações que conjuravam a deflagração de um novo conflito. No entanto, ao modificarem sua memória e os seus discursos subsequentes, a fim de se adaptarem ao presente, criando uma nova imagem - e porque não dizer: história - do seu passado e, ao mesmo tempo, um novo laço identitário, os comunistas não conseguiram realizar tal tarefa sem conflitos, dilemas e tensões. Conforme revela Pollak, além da memória ser seletiva, ela "sofre flutuações que são em função do momento em que ela é articulada" 
(1992: 04). Desse modo, pode-se afirmar que a memória pode mudar, e é nesse sentido que ela é um ato do presente (LE GOFF, 1990). Assim, o episódio da luta pela paz das décadas de 1940 e 1950 foi apropriado pelos comunistas de modo a "enquadrarem-se" nas lutas políticas do seu tempo e, ao mesmo tempo, manterem a coesão interna do partido e defenderem suas fronteiras, tanto externas (opondo-se aos capitalistas que, igualmente, afirmavam-se defensores da paz) quanto internas (militantes divergentes). ${ }^{10}$

Importa ressaltar que as flutuações atravessadas pela memória também se davam em virtude das alterações nas linhas políticas do partido. De 1943 até 1947, é sabido, o Partido Comunista do Brasil adotou uma linha política moderada, de não enfrentamento com o governo, chamada de "União Nacional". Não obstante, a partir de 1947, a linha política foi alterada, passando a pregar e a desenvolver a luta armada para a tomada do poder. Em 1950, a linha de radicalidade foi consolidada, oficialmente, com o documento intitulado Manifesto de Agosto. Naquele momento, a mobilização da população para a revolução armada tornou-se o centro das ações dos comunistas brasileiros. Todavia, a cada mudança de linha política o PCB ajustava o passado de acordo com as preocupações do presente. A adoção de uma postura de revolução armada coincidiu com o período mais quente da Guerra Fria. ${ }^{11}$ Com isso, na medida em que a conjuntura mostrava-se mais crítica - como foi o caso da Guerra da Coreia (1950-1953) -, a memória sofria mais ajustes e o laço identitário com o pacifismo estreitava-se.

Até o ano de 1956, os comunistas vão desenvolver e propagandear as campanhas em favor da paz. A partir de então, sobretudo após a divulgação do relatório Krushev, no qual foram revelados os crimes cometidos por Stálin, é possível perceber uma significativa queda nos chamamentos pela paz. A imprensa comunista, durante aquele ano, e nos primeiros seguintes, pouco divulgou, principalmente se comparado a anos anteriores, assuntos relativos às campanhas do "Movimento pela Paz". Naquele momento, críticas à organização do Partido e ao culto à personalidade invadiram as páginas dos jornais e as cabeças dos militantes.

No que concerne ao Brasil, é relevante destacar que os comunistas procuravam envolver-se em campanhas e movimentos de diferentes naturezas a fim de continuarem participando da vida política do país e não se desestruturarem a ponto de extinguirem-se

\footnotetext{
${ }^{10}$ Havia militantes que não concordavam com a tese de luta pela paz e de colher assinaturas para as campanhas pacifistas. Estes acreditavam que a luta armada para a tomada do poder e a derrubada do capitalismo no Brasil deveriam ser as principais preocupações do partido e a concentração de todas suas energias (CORRÊEA, 1994).

${ }^{11}$ De acordo com diversos historiadores, o período mais crítico da Guerra Fria compreendeu os anos entre 1947, ano do lançamento da Doutrina Truman, e 1953, ano em que terminou a Guerra da Coreia.
} 
enquanto instituição política. Como destaca o militante comunista Moisés Vinhas, o que impedia os comunistas de desaparecer como força política efetiva era "provavelmente sua participação em campanhas pela paz, contra a bomba atômica, na qual conseguem reunir milhares de assinaturas" (VINHAS, 1982: 96). Dessa maneira, afirma o militante que essas campanhas mantinham "algumas franjas de sua política ligadas à realidade do país" (1982: 96).

Em resumo, até a Segunda Guerra Mundial, o comunismo internacional e sua seção brasileira, o PCB, se filiavam a identidade de revolucionários. Contudo, a partir do fim daquele conflito e, principalmente, a partir da Guerra Fria, os comunistas passaram a se filiar também à identidade de pacifistas, criando todo um imaginário de verdadeiros defensores da paz. Assim, a partir daquele momento, os comunistas, além de arrogarem para si a identidade de revolucionários, vanguarda do proletariado, defensores das classes trabalhadoras, passaram a criar e a elaborar um laço identitário com o pacifismo, apresentando-se como legítimos defensores da paz mundial, reconstruindo, ainda, a memória do partido (PCUS), da URSS e do comunismo acerca de suas origens pacifistas. Todavia, o pacifismo soviético durante a primeira década da Guerra Fria, pode-se dizer, ficou quase que exclusivamente no âmbito propagandístico.

\section{Fontes}

\section{Arquivos}

Arquivo Nacional. MJ/Segurança Nacional. Panfletos Ij1 1325, ano de 1950.

Arquivo Público do Estado do Rio de Janeiro (APERJ). Dossiê - DPS - Polícia Política, Dossiê n ${ }^{0} 30060$.

\section{Periódicos}

O Jornal (1949-1956).

Problemas (1947-1956).

Voz Operária (1948-1956).

\section{Memórias e biografias}

CORRÊA, Hércules (1994). Memórias de um stalinista. Rio de Janeiro, Opera Nostra. VINHAS, Moisés (1982). O Partidão: a luta por um partido de massas (1922-1974). São Paulo, Hucitec.

\section{Referências bibliográficas}


BACZKO, Bronislaw (1985). Imaginação social. In Enciclopédia Einaudi - AnthroposHomem, Lisboa, Imprensa Nacional - Casa da Moeda, vol. 5.

CLAUDIN, Fernando (1970). La crisis del movimiento comunista. De la Komintern al Kominform. Paris, Ruedo Ibérico.

DELMAS, Claude (1979). Armamentos nucleares e Guerra Fria. Editora Perspectiva, São Paulo.

DEUTSCHER, Isaac (1970). Stalin. A história de uma tirania. Rio de Janeiro, Civilização Brasileira, 2 vols.

FERREIRA, Jorge (2002). Prisioneiros do mito. Cultura e imaginário político dos comunistas no Brasil. Niterói: EdUFF: Rio de Janeiro: MAUAD.

HOLLOWAY, David (1997). Stalin e a bomba. Rio de Janeiro: Record.

LE GOFF, Jacques (1990). História e Memória. Campinas, Ed. Unicamp,

MARIANI, Bethania (1998). O PCB e a imprensa: os comunistas no imaginário dos jornais (1922-1989). Rio de Janeiro: Revan; Campinas, São Paulo. UNICAMP.

OLIVEIRA, Odete Maria de (1999). Os descaminhos do Brasil Nuclear. Ijuí: Unijuí.

POLLAK, Michel (1989). Memória, esquecimento, silêncio. Estudos Históricos, Rio de Janeiro, vol. 2, n. 3, p. 3-15. . (1992). Memória e identidade social. Estudos Históricos, Rio de Janeiro, vol. 5, n. 10, pp. 200-212.

REIS FILHO, Daniel Aarão (1997). Uma Revolução Perdida: a história do socialismo soviético. São Paulo, Editora Fundação Perseu Abramo.

RIBEIRO. Jayme Fernandes (2011). Combatentes da paz: os comunistas brasileiros e as campanhas pacifistas dos anos 1950. Rio de Janeiro, 7 Letras/FAPERJ. . (2007). Os "inimigos da paz": Estado, imprensa e a repressão ao movimento dos partidários da paz no Brasil (1950-1956). Saeculum - Revista de História, [17]; João Pessoa, jul/ dez.

ROUSSO, Henry (1985). Vichy, le grande fossé. Vingtième Siècle. n. 5.

THOMPSON, E. P. (org.). (1985). Exterminismo e Guerra Fria. Editora São Paulo, Brasiliense.

VIZENTINI, Paulo G. Fagundes (2000). A Guerra Fria. In REIS FILHO, Daniel Aarão, FERREIRA, Jorge e ZENHA, Celeste (orgs.). O Século XX - O tempo das crises: revoluções, fascismos e guerras. Rio de Janeiro: Civilização Brasileira.

Artigo recebido em 29 de maio de 2020

Aprovado em 03 de julho de 2020

DOI: $10.12957 /$ intellectus.2020.51371 